\title{
The program of support of small enterprises: data for Russia
}

\author{
Программа поддержки малых предприятий: данные по России
}

Received: March 6, 2019

Accepted: April 13, 2019

\author{
Written by: \\ Iuliia S. Pinkovetskaia ${ }^{8}$ \\ ORCID ID 0000-0002-8224-9031
}

\begin{abstract}
The aim of research was to study the features of support for small enterprises specialized in various types of economic activity in Russia. The specific weights of the number of recipients of support in the total number of small enterprises in 14 sectors, as well as the structure of support in five main forms are determined. Official empirical data for 2015 were used as initial data. It is shown that support is provided to $2 \%$ of all small enterprises. At the same time, the main direction is financial support, and the highest level of support is noted in agriculture.
\end{abstract}

Keywords: small enterprises, types of economic activity, financial support, information support, consulting support.

\begin{abstract}
Аннотация
Целью исследования явилось изучение особенностей поддержки малых предприятий, специализирующихся на различных видах экономической деятельности в России. Определены удельные веса количества получателей поддержки в общем количестве малых предприятий по 14 отраслям, а также структура поддержки по пяти основным формам. В качестве исходных данных использовались официальные эмпирические данные за 2015 год. Показано, что поддержка оказывается $2 \%$ всех малых предприятий. При этом основным направлением является финансовая поддержка, причем самый высокий уровень поддержки отмечается в сельском хозяйстве.
\end{abstract}

\section{Ключевые слова:}

малые предприятия, виды экономической деятельности, финансовая поддержка, информационная помощь, консультации

referred to as MP), as experience shows, are the most important factor in regional development, especially in underdeveloped areas, and create conditions for structural adjustment of the economy (Acs et al., 2008; Baumol, 2004;. Decker et al., 2014; Pinkovetskaia, 2019a; Pinkovetskaia, 2019b; Pinkovetskaia et al., 2019a; Pinkovetskaia et al., 2019b; Kiseleva et al., 2019). Given the above, the study of the current level of support for small businesses on state and municipal programs is relevant.

\footnotetext{
${ }^{8} \mathrm{PhD}$ (Economics), Associate Professor Department of Economic Analysis and State Management, Ulyanovsk State University, Russia
} 
In recent years, a number of works by Russian authors on the problems of supporting small and medium-sized businesses in Russia and certain regions have been published. The following articles are of the greatest interest among them. Averin (2016) analyzed the total volume of SME lending and presented the characteristics of their lending market in Russia and Moscow. Vasilyeva and Safrygina (2016) on the basis of statistical data analyzed some existing programs to support small and medium-sized businesses and noted the presence of positive changes in the support tools. In the article. Zaychenkov (2015) the results of sample surveys of enterprises and presents the results of the scoring of the business environment in St. Petersburg, including different areas of its support. In the work of Ivanova and Vishnevsky (2017 the analysis of existing restrictions of development of various types of activity is given and the tools of support of business allowing to overcome these restrictions are offered. In the article. The issues (Magaziner, 2017) of state support of small businesses through the development and implementation of various financial instruments. He compared the experience of state support in developed countries with this activity in Russia. Kurbanova (2016) considered such instruments of financial assistance to small business as state guarantees for its lending, as well as the use of risk insurance programs. Article by Minakova, Orlova and Lazarenko (2015) is devoted to such elements of state support of MP in Russia as grants, development of microfinance, as well as creation of specialized infrastructure of property support. Shilov (2017) considers features of such channels of financial support of MP as Bank crediting and microfinance. At the same time, a comprehensive analysis of the current level of support for small and medium-sized businesses in all types of economic activity has not been paid the necessary attention to date. In the work of Sidorchuk (2012) issues of consulting support of small and medium-sized enterprises are considered.

The purpose of the study, the results of which are presented in this article, was to analyze the existing patterns characterizing the level of support for small enterprises specialized in various types of economic activity in Russia. At the same time, the following tasks were solved: the proportion of the number of small enterprises that are recipients of support in the total number of enterprises, as well as the existing level of support in its main forms.

\section{Materials and Methods}

The research methodology is based on the consideration of small and medium-sized enterprises specialized in 14 types of economic activities. The first phase identified the number of small enterprises (including microenterprises) operating in 2015 and the number of enterprises that received support under state and municipal programmes that year. On the basis of these data for each of the types of economic activity, the proportion of recipients of support in the total number of small enterprises was determined.

At the second stage of the work, the existing levels of support in its main forms (directions) were calculated. The levels of support were assessed on the basis of the proportion of small enterprises that benefited from different forms of support from the total number of enterprises that received support. At the same time, five main forms of support established by Federal law No. 209-FZ of 24 July 2007 were considered (On the development, 2019):

- financial (1 form);

- information (2 form);

- consultation (3 form);

- property (4 form);

- training, retraining and advanced training of employees (form 5).

It should be noted that the same small enterprise could benefit from support in several forms.

The study was based on the official information of the Federal state statistics service (2019), namely the results of continuous monitoring of the activities of small and medium-sized businesses in 2015. It should be noted that the data of continuous observations of surveys conducted in accordance with the current legislation, once every five years, provide the most accurate information.

\section{Results and Discussion}

The characteristic of support of small enterprises according to the state and municipal programs is given in table. 1. It presents the number of enterprises engaged in each of the activities in 2015 , as well as the number of enterprises that were recipients of support. In column 4 of table. 1. the share of recipients of support in the total number of small enterprises is indicated. 
Table 1.

Characteristics of small enterprises support in 2015

\begin{tabular}{|c|c|c|c|}
\hline $\begin{array}{l}\text { Types of economic } \\
\text { activity }\end{array}$ & $\begin{array}{l}\text { Enterprises operating } \\
\text { in } 2015\end{array}$ & $\begin{array}{l}\text { Enterprises that were } \\
\text { recipients of support }\end{array}$ & $\begin{array}{l}\text { Share of recipients of } \\
\text { support in the total number } \\
\text { of enterprises, } \%\end{array}$ \\
\hline agriculture & 32155 & 12026 & 37.40 \\
\hline fishing, fish farming & 2045 & 221 & 10.81 \\
\hline mining & 3646 & 46 & 1.26 \\
\hline manufacturing & 141360 & 4566 & 3.23 \\
\hline $\begin{array}{l}\text { production and } \\
\text { distribution } \\
\text { of electricity, gas and } \\
\text { water }\end{array}$ & 9130 & 279 & 3.06 \\
\hline construction & 159548 & 1691 & 1.06 \\
\hline wholesale and retail & 523015 & 3554 & 0.68 \\
\hline $\begin{array}{l}\text { transport and } \\
\text { communications }\end{array}$ & 100432 & 1259 & 1.25 \\
\hline financial activities & 17909 & 304 & 1.70 \\
\hline hotels and restaurants & 44360 & 512 & 1.15 \\
\hline real estate transactions & 345537 & 2939 & 0.85 \\
\hline education & 4481 & 103 & 2.30 \\
\hline healthcare & 28149 & 717 & 2.55 \\
\hline $\begin{array}{l}\text { provision of public, } \\
\text { social and personal } \\
\text { services }\end{array}$ & 37902 & 769 & 2.03 \\
\hline all types of activities & 1449669 & 28986 & 2.00 \\
\hline
\end{tabular}

In 2015 received the support of slightly less than 29 million small businesses. At the same time, the largest number (more than $40 \%$ ) of recipients of support belonged to agriculture. This situation seems logical in connection with the solution of a wide range of problems of import substitution. A significant number of beneficiaries (almost 16\%) belong to manufacturing industries. More than 1.200 recipients of support also took place in activities such as wholesale and retail trade, real estate, construction, transport and communications. In
General, 26 thousand $(89.8 \%)$ small enterprises of the six economic activities mentioned above were supported.

The analysis of the share of recipients of support in the total number of small enterprises showed that on average only $2 \%$ of all small enterprises operating in 2015 were recipients of support. At the same time, the data given in table. 1 showed a significant differentiation of these indicators by type of activity. A very high level of support was observed in 2015 
in agriculture, where more than a third of all small businesses received various types of support. It should be noted that the share of recipients of support in agriculture was 18 times higher than the average for all activities. A high level of support (10.8\%) took place in fishing, fish farming. Despite the tasks for the development of small enterprises in the manufacturing sector, which are widely declared in the official programs, the share of recipients of support in the manufacturing industry was a little more than $3 \%$. The level of support in wholesale and retail trade $(0.68 \%)$, as well as real estate transactions $(0.85 \%)$ seems low. At the same time, the absolute values of the number of recipients of support in these industries, as noted earlier, are quite large (respectively 3554 and 2 939) enterprises. For most activities, the share of beneficiaries in the total number of small enterprises ranged from $1 \%$ to $3 \%$.
In general, the analysis showed that there are great potential opportunities for increasing the support of small enterprises by state and municipal authorities in the coming years.

Support for small enterprises was provided in five main forms. The assessment of how often the enterprises that received support in 2015 took advantage of its various forms is given in the table. 2. For each of the forms of support whose conditional numbers were specified earlier, it shows the proportion of the number of recipients of support who used this particular form. The information in the table is presented by type of economic activity. As already noted, small businesses could benefit from several forms of support at the same time.

Table 2.

Share of various forms of support, \%

\begin{tabular}{|c|c|c|c|c|c|}
\hline \multirow{2}{*}{ Types of economic activity } & \multicolumn{5}{|c|}{ Forms of support small enterprises } \\
\hline & 1 & 2 & 3 & 4 & 5 \\
\hline agriculture & 97.67 & 6.21 & 6.21 & 0.59 & 1.31 \\
\hline fishing, fish farming & 90.05 & 7.69 & 8.14 & 2.26 & 2.26 \\
\hline mining & 86.96 & 10.87 & 15.22 & 4.35 & 4.35 \\
\hline manufacturing & 86.44 & 11.13 & 9.07 & 2.39 & 3.04 \\
\hline $\begin{array}{l}\text { production and distribution } \\
\text { of electricity, gas and } \\
\text { water }\end{array}$ & 88.53 & 8.24 & 7.17 & 5.38 & 4.66 \\
\hline construction & 73.57 & 15.38 & 13.78 & 3.25 & 7.45 \\
\hline wholesale and retail & 65.64 & 21.44 & 16.91 & 5.63 & 6.89 \\
\hline transport and communications & 77.12 & 14.61 & 12.87 & 3.26 & 4.29 \\
\hline financial activities & 89.14 & 28.95 & 26.97 & 9.54 & 8.22 \\
\hline hotels and restaurants & 64.65 & 20.90 & 14.26 & 6.25 & 7.62 \\
\hline real estate transactions & 67.03 & 19.43 & 14.66 & 7.42 & 8.27 \\
\hline education & 76.70 & 13.59 & 11.65 & 5.83 & 10.68 \\
\hline healthcare & 80.75 & 11.16 & 9.34 & 7.25 & 3.77 \\
\hline $\begin{array}{l}\text { provision of public, } \\
\text { social and personal services }\end{array}$ & 74.64 & 14.04 & 12.22 & 9.49 & 4.42 \\
\hline all types of activities & 84.63 & 11.99 & 10.22 & 3.13 & 3.87 \\
\hline
\end{tabular}


The most widespread in 2015 was the financial form of support for small businesses. It was used by almost $85 \%$ of all enterprises receiving support. The highest level of financial support (more than 90\%) was observed in such activities as agriculture fishing and fish farming. The smallest share of enterprises using this form of support (less than 70\%) was in wholesale and retail trade, real estate transactions, as well as hotels and restaurants.

A little more than $10 \%$ of all small businesses that received support used such forms as information and consulting. At the same time, the high level of information support needs was noted in financial activities (about 29\%), as well as wholesale and retail trade, real estate transactions, hotels and restaurants (about 20\%). Consulting support was in high demand (almost 27\%) in enterprises engaged in financial activities.

Such forms of support as property, as well as training, retraining and advanced training of employees did not receive significant development in 2015, they were used by less than $4 \%$ of enterprises that received support. At the same time, more than $8 \%$ of small enterprises received appropriate support in such activities as the provision of public, social and personal services, financial activities, education, real estate operations.

\section{Conclusions}

The results of the research with scientific novelty include the following:

- it is shown that in 2015 only a little less than 29 thousand small enterprises received support, which is only $2 \%$ of all enterprises. More than $40 \%$ of recipients of support belonged to agriculture;

- it is proved that among the small enterprises that received support $89.8 \%$ belong to such activities as agriculture, manufacturing, wholesale and retail trade, real estate operations, construction, transport and communications;

- it is shown that there is a significant differentiation of enterprises that were supported by types of economic activity;

- low level of support was noted in manufacturing enterprises;

- it is shown that the most widespread in 2015 was the financial form of support for small enterprises, which reached $85 \%$ of all enterprises receiving support. The highest level of financial support (more than 90\%) was observed in such activities as agriculture fishing and fish farming;
- $\quad$ it is proved that a little more than $10 \%$ of all small businesses that received support used such forms as information and consulting. At the same time a high level of needs for information and consulting support was noted in financial activities;

- it is shown that such forms of support as property, as well as training, retraining and advanced training of employees have not received significant development.

The results of the research have a certain theoretical and practical significance. The analysis showed that support was provided to a relatively small number of small enterprises. Therefore, there are great potential opportunities to increase such activities in accordance with state and municipal programs in the coming years. Particularly important is the development of such forms of support for small enterprises as training, retraining and advanced training of employees. Its main directions, in our opinion, are the formation of educational programs on the theory and practice of entrepreneurship, taxation, accounting and reporting, lending, leasing, as well as the possibility of participation of entrepreneurs in a variety of programs to support them.

The practical significance of the research results is associated with the possibility of their use directly by entrepreneurs (especially beginners) in determining the possibilities and directions of using existing forms of support in their activities. In addition, the results can be used by departments of regional and municipal governments in the development of measures to regulate and support the activities of small and medium-sized businesses, especially in those activities where it has not received sufficient development.

\section{References}

Acs Z., Desai S. \& Hessels J. (2008). Entrepreneurship, economic development and institutions. Small Business Economics, 31, 219234.

Averin A.V. (2016). Main directions of improving the system of financial support for entrepreneurship. Power systems, 1(1), 6-9.

Baumol W. J. (2004). Entrepreneurial enterprises, large established firms and other components of the free-market growth machine. Small Business Economics, 23, 9-21.

Decker R., Haltiwanger J., Jarmin R. \& Miranda J. (2014). The Role of Entrepreneurship in US Job Creation and Economic Dynamism. Journal of Economic Perspectives, 28(3), 3-24. 
Federal state statistics service. Continuous monitoring of the activities of small and mediumsized businesses in 2015. URL: http://www.gks.ru/free_doc/new_site/business/pro m/small_business/itog2015/itog-spn2015.html (accessed 2.07.2019).

Ivanova T. \& Vishnevsky V. (2017). Small and medium business: development constraints and tools to overcome them / in the collection: Problems and prospects of economic development of regions. Collection of articles of the all-Russian scientific and practical conference dedicated to the 45th anniversary of the Institute of Economics and Finance, 53-58.

Kiseleva, O., Lebedev, A., Pinkovetskaia, I., RojasBahamón, M., \& Arbeláez Campillo, D. (2019). Specialization and concentration of small and medium enterprises employees: Russian data. Amazonia Investiga, 8(20), 6-15.

Kurbanova M. (2016). Financing of small business in subjects of the Russian Federation. Success Factors, 1(6), 29-35.

Magaziner I. (2017). Financial instruments of support of subjects of small business by the Russian banks with the state participation. In the collection: Scientists economists of St. Petersburg - to the Petersburg international economic forum the collection of scientific articles. Saint-Petersburg. 4758.

Minakova E., Orlova S. \& Lazarenko L. (2015). Development of infrastructure of state support of small and medium enterprises in Russia and abroad. Fundamental researches, 2(13), 2925-2929.

Pinkovetskaia, I. (2019a). Indicadores económicos de la actividad de las pequeñas y medianas empresas en Rusia. Revista Científica Del Amazonas, 2(4), 517.

Pinkovetskaia, I., Nuretdinova, Y., Treskova, T., \& Neif, N. (2019a). Estimation of fixed capital investment in Russian small enterprises and microenterprises in 2018. Amazonia Investiga, 8(21), 42-51.

Pinkovetskaia I., Balynin I., Arbelaez Campillo D. \& Rojas Bahamon M. (2019b). Small business development in Russia: results of the assessment of sectoral structure and number of employees. Revista ESPACIOS, 40(07), 1-16.

Pinkovetskaia, I. (2019b). Evaluación de la concentración del emprendimiento en las regiones de Rusia. Revista Científica Del Amazonas, 2(4), 1826.

On the development of small and medium-sized enterprises in the Russian Federation: Federal law No. 209-FZ of 24.07.07. URL: https://rg.ru/2007/07/31/biznes-doc (accessed 2.07.2019).

Shilov V. (2017). Problems of crediting of subjects of small and average business in Russia. Azimut of scientific researches: economy and management, 6(1), 213-216.

Sidorchuk R. (2012). State and municipal support of small and medium enterprises (SMEs) in Russia. Marketing MBA. Marketing management of the enterprise, 2, 4-25.

Strategy for the development of small and mediumsized enterprises in the Russian Federation for the period up to 2030: government Order No. 1083-R of June 2, 2016. (2016). Collection of legislation of the Russian Federation. No. 24. 3549.

Vasilyeva O. \& Safrygina E. (2016). Support of SMEs in the current economic conditions - what is the best way for the state to focus its efforts? Bulletin of the Moscow state regional University. Series: Jurisprudence, 1, 81-91.

Zaichenko S. (2015). Directions of improvement of mechanism of state support of entrepreneurship in Saint-Petersburg, Russia. Economy and management, 8(118), 46-53. 